\title{
Cost Avoidance of Drug Information Services at the Mental Hospital in Saudi Arabia
}

\author{
Yousef Ahmed Alomi ${ }^{1, *}$, Nora Alsulami ${ }^{2}$, Nada Al Qahtani ${ }^{3}$, Mohamed Mashouf Al Qahtani ${ }^{4}$, \\ Fahad Abdallah Almansor ${ }^{5}$ \\ ${ }^{1}$ The Past General Manager of General Administration of Pharmaceutical Care and Head, National Clinical pharmacy, Pharmacy \\ Practice and Pharmacy $R$ and D Administration, Ministry of Health, Riyadh, KSA. \\ ${ }^{2}$ Head, Pharmaceutical Care Administration, Al-Amal Medical Complex, Riyadh, KSA. \\ ${ }^{3}$ Head, Drug Information Center, Pharmaceutical Care Administration, Al-Amal Medical Complex, Riyadh, KSA. \\ ${ }^{4}$ Executive Director, Al-Amal Medical Complex, Riyadh, KSA. \\ ${ }^{5}$ Medical Director, Al-Amal Medical Complex, Riyadh, KSA.
}

Received: 28 February 2018; Accepted: 01 May 2018

*Correspondence to:

Dr. Yousef Ahmed Alomi, The Past General Manager of General Administration of Pharmaceutical Care Past Head, National Clinical pharmacy, and pharmacy practice Past Head, Pharmacy R and D Administration Ministry of Health, P.O.BOX 100, Riyadh 11392, Riyadh, SAUDI ARABIA.. Email: yalomi@gmail.com

Copyright: (C) the author(s),publisher and licensee Indian Academy of Pharmacists. This is an open-access article distributed under the terms of the Creative Commons Attribution Non-Commercial License, which permits unrestricted non-commercial use, distribution, and reproduction in any medium, provided the original work is properly cited.

\begin{abstract}
Objective: To explore the cost-efficiency of drug information services at the mental hospital in Saudi Arabia. Methods: It simulation of cost efficiency of drug information center for four years and a half at a mental hospital in Saudi Arabia. It estimated cost avoidance of running drug information services. Drug information services started from answering inquiries from healthcare providers including a physician, pharmacist, and nurses. The estimated cost of using international Study Model. The value considered were the expected results of drugrelated problems sequel to drug information inquiries; if not existing drug information services and were not answered; starting from Physician visit, additional laboratory test, further treatment, hospital admission, Critical care admission to death stage. The cost estimated for each step. All value used in USA solar currency. Results: The total of drug information inquiries answered with cost avoidance reported was (1084). The total estimated cost avoidance of answered drug information inquiries was $(167,623.50)$ USD with average cost avoidance was (154.63) USD per each inquiry. The most type inquiries estimated cost avoidance was drug dosing $(117,316.50)$ USD followed by the drug of choice $(17,960.00)$ USD and drug interaction $(14,024.50)$ USD. The most estimated cost avoidance by a used references assistant to answer the question and prevent drug-related problem was Drugs.com website $(118,683.50)$ USD, followed by Lexi comp-drug information $(100,064.50)$ USD and prescribing guidelines in psychiatry $(18,642.00)$ USD. The most cost avoidance related to drug information caller was physician $(135,787.50)$ USD, pharmacist $(28,624.50)$ USD and patients $(2,342.50)$ USD. Conclusion: The drug information services are saving a high cost per year despite limited resources. The drug information services with different type need to expand to all departments at a Mental hospital in Riyadh city, Saudi Arabia.
\end{abstract}

Key words: Cost avoidance, Drug information, Mental hospital, Ministry of Health, Saudi Arabia.

\section{INTRODUCTION}

The drug information services founded at Ministry of Health hospitals in the past twenty several years. ${ }^{[1]}$ The network of drug information centers recently established as part of pharmacy strategic plan. ${ }^{[2]}$ Several studies did overall the world about drug information inquiries including Middle East counties ${ }^{[3]}$ The measurements of the cost influence of drug information centers rarely founded in the world. The first study was done by the first author with the cost efficiency of national drug information center at Ministry of Health. ${ }^{[4]}$ The drug information center corner all type of specialties including mental health services. The measurements of the economic impact of drug information services at the psychiatric hospital seldom found in the high development healthcare system and pharmacy practice. ${ }^{[5-10]}$ The authors are not familiar with any investigation about cost avoidance of running drug information services at the mental hospital. The objective of the study to explore the economic impact and cost avoidance of drug information services at the mental hospital in Riyadh city, the Kingdom of Saudi Arabia.

\section{METHOD}

It is a simulation of cost efficiency of drug information center for four years and a half at a mental hospital in Saudi Arabia. It 600-bed of Psychiatry and addition hospitals in Riyadh city. It had inpatient admission and ambulatory care clinics, and Emergency departments. The hospital had a different specialty for adults and pediatrics. The hospital treats the common psychiatric illness including depression, bipolar and schizophrenia. In addition to addiction diseases. The hospital had pharmacy serve the patient including inpatient pharmacy with units dose drug distribution system, outpatient pharmacy, and home healthcare services, and drug information center. The pharmacy computerized physician order entry with an electronic prescription. The pharmacy clinical pharmacy and satellite pharmacy to monitor and follow the patient. Also, the clinical pharmacist shared in the round with the medical team and operated clozapine and patient counseling clinics. The pharmacy had medications safety program and with electronic clinical pharmacy documentation. In addition to annual pharmacy psychiatric symposium and clinical and pharmacy student training programs. The drug information center 


\section{Alomi, et al:: Study about Cost avoidance of drug information services}

receiving inquiries from healthcare staff over eight hours per days for five days per a week, updated the hospital formulary and make drug evaluation for a new addition or deletion from hospital formulary, and participated in the Pharmacy and Therapeutic committees. Also, the drug information shared in the training of pharmacy students, pharmacy staff, and distribute public drug information to all visitors. It estimated cost avoidance of running drug information services. Drug information services started from answering inquiries from healthcare providers including a physician, pharmacist, and nurses. The estimated cost of Using international Study Model. ${ }^{[7]}$ The cost considered were the expected results of drug-related problems sequel of drug information inquires if not existing drug information services and were not answered; starting from Physician visit, additional laboratory test, additional treatment, hospital admission, Critical care admission to death stage. The cost was estimated for each stage. All cost used in USA solar currency. The format analyzed through the Microsoft Excel sheet version 10th.

\section{RESULTS}

The total of drug information inquiries answered with cost avoidance reported was (1084). The total estimated cost avoidance of answered drug information inquiries was $(167,623.50)$ USD, annually was $(37,249.66)$ USD with average cost avoidance was (154.63) USD per each inquiry as explored in Table 1. The most type inquiries estimated cost avoidance was drug dosing $(117,316.50)$ USD followed by the drug of choice $(17,960.00)$ USD and drug interaction $(14,024.50)$ USD. While the highest cost avoidance per each inquiry was pharmacoeconomics (570.50) USD, Drug dosing (434.51) USD, and poisoning and toxicology (284.50) USD as explored in Table 2. The most estimated cost avoidance by a used references assistant to answer the question and prevent drug-related problem was Drugs.com website (118,683.50) USD, followed by Lexicomp-drug information $(100,064.50)$ USD and prescribing guidelines in psychiatry $(18,642.00)$ USD as explored in Table 3 . The most cost avoidance related to drug information caller was physician $(135,787.50)$ USD, pharmacist $(28,624.50)$ USD and patients $(2,342.50)$ USD as explored in Table 4.

\section{DISCUSSION}

Over the past several of implementation pharmacy strategic plan at Ministry of Health institutions. ${ }^{[2]}$ More than thirty pharmacy practice implemented with emphasis on the clinical practice to improve patient outcome, facilitate the healthcare to the patient and reduced healthcare economic burden. ${ }^{[1]}$
The pharmacy administration established several key performance indicators for the program including the economic impact of the pharmacy services. ${ }^{[2]}$ The national pharmacy psychiatric program implemented at more twenty mental hospitals. The drug information services were a part of them. The measurements of cost influence of the drug information services done in the study. The results of the study showed that is a high-cost avoidance of answering drug information inquiries and prevention of expected drugrelated problems over the four years and a half. Although the number of questions is very low however; the cost impact was high. That is related to the important of drug information inquiries and complications sequencing if not answering. The total cost avoidance in the concern mental hospital less than what published in the national and international literatures. That's related number of drug information inquiries number less that's mentioned in the past studies. All investigations done at normal hospitals not mental one. However, that's best comparison with previous results because the study first done in psychiatric field in the Middle East and rest of countries around the world. ${ }^{[4,7-10]}$ The most type of inquiries cost avoidance was drug dosing and this is normal finding because most of the inquiries were drug dosing. Followed by drug of choice type that's related the management guidelines of not followed or not existed may impact of several complications and either increase length of hospital stay of increase the number admission of ambulatory care or emergency visit. The drug interaction type plant big role at mental hospital because a lot antipsychotic drug interaction may lead to several complications and it is normal to find it as third cost avoidance type of inquiries. The results showed the highest net saving type per each inquiry was PharmacoEconomic or poisoning after drug dosing because the number of questions are very low if compared with drug dosing. The drug.com the highest reference use to answer high cost avoidance inquiries and this normal because it was the most references used. While Lexicomp drug information seldom used and it was second one of cost avoidance of question answered. That's because of the complicated and important question answered through this reference. The results should the physician most cost avoidance of answered drug information inquiries despite it was not the highest caller utilization of drug information services. That's normal finding because the high related problems sequences asked by them. All previous results related cost avoidance detail related type of drug information inquiries, type of drug information resources and type of caller not compared with previous literature because it not available.

\begin{tabular}{|l|l|l|l|}
\hline \multicolumn{5}{|l|}{ Table 1: Cost avoidance of drug information inquiries. } \\
\hline $\begin{array}{l}\text { Type consequences of cost avoidance of } \\
\text { answered drug information inquires }\end{array}$ & Responses & Percentage & Total Cost \\
\hline 0-no medication related problem-0\$ & 342 & $31.55 \%$ & 0.00 \\
\hline 1- no change in therapy or no harm-0\$ & 94 & $8.67 \%$ & 0.00 \\
\hline 2-physician visit-64.50\$ & 643 & $59.32 \%$ & $41,473.50$ \\
\hline 3-a- additional test-159.50\$ & 24 & $2.21 \%$ & $3,828.00$ \\
\hline 3-b-non-invasive procedure-343.50\$ & 7 & $0.65 \%$ & $2,404.50$ \\
\hline 4-a-additional treatment-386.50\$ & 20 & $1.85 \%$ & $7,730.00$ \\
\hline 4-b-additional treatment/non invasive procedure-570.50\$ & 1 & $0.09 \%$ & 570.50 \\
\hline 4-c-increased length of stay-3,168.50\$ & 0 & $0.00 \%$ & 0.00 \\
\hline 5-a-transferred to ICU-5,808.50\$ & 2 & $0.18 \%$ & $11,617.00$ \\
\hline 5-b-long term care admission-10,379.97\$ & 0 & $0.00 \%$ & 0.00 \\
\hline 6-death-100,000.000\$ & 1 & $0.09 \%$ & $100,000.00$ \\
\hline Answered & 1084 & & $167,623.50$ \\
\hline Skipped & 4 & & \\
\hline Cost avoidance per inquiry & & & 154.6342 \\
\hline
\end{tabular}


Alomi, et al.: Study about Cost avoidance of drug information services

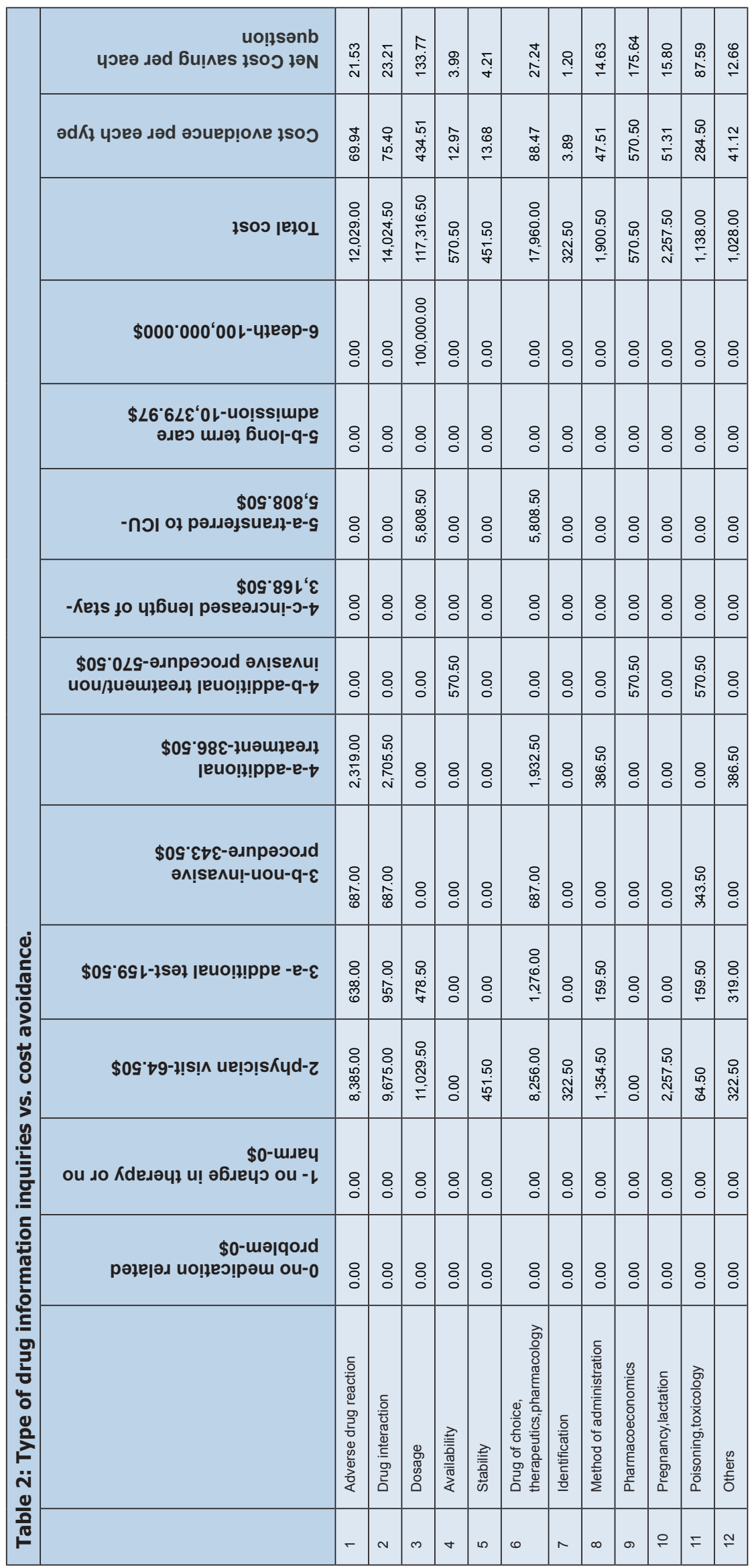


Alomi, et al.: Study about Cost avoidance of drug information services

\begin{tabular}{|c|c|c|c|c|c|c|c|c|}
\hline & 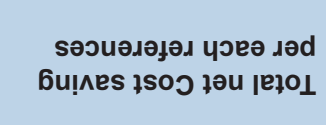 & $\begin{array}{l}\stackrel{0}{+} \\
\stackrel{+}{+} \\
\tilde{\sigma}\end{array}$ & 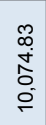 & \begin{tabular}{l}
$\infty$ \\
$\infty$ \\
$\infty$ \\
$\infty$ \\
0 \\
0 \\
\hdashline \\
\hdashline
\end{tabular} & $\underset{\substack{i \\
N}}{\Sigma}$ & $\begin{array}{l}\mathbb{N} \\
0 \\
0 \\
0 \\
0 \\
0\end{array}$ & 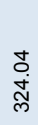 & $\begin{array}{l}\tilde{m} \\
\text { 心. } \\
\tilde{m} \\
\infty \\
\infty\end{array}$ \\
\hline & 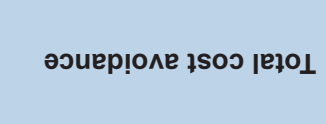 & $\begin{array}{l}\overbrace{0} \\
\infty_{0} \\
0 \\
\infty \\
\stackrel{\infty}{=}\end{array}$ & 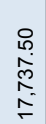 & 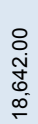 & $\begin{array}{l}8 \\
\text { ¿ } \\
\stackrel{\$}{N}\end{array}$ & $\begin{array}{l}\stackrel{0}{10} \\
\dot{0} \\
\stackrel{0}{0} \\
\stackrel{0}{0}\end{array}$ & 㝵 & 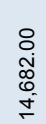 \\
\hline & \$000`000‘00เ-чұеәр-9 & $\begin{array}{l}\stackrel{8}{\circ} \\
\stackrel{8}{0} \\
\stackrel{0}{\circ}\end{array}$ & $\stackrel{8}{0}$ & $\stackrel{8}{\circ}$ & $\stackrel{8}{8}$ & $\begin{array}{l}8 \\
8 \\
8 \\
8 \\
\dot{0}\end{array}$ & $\stackrel{8}{\circ}$ & $\stackrel{8}{8}$ \\
\hline & 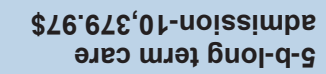 & $\stackrel{8}{0}$ & 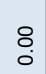 & $\stackrel{8}{0}$ & $\stackrel{8}{0}$ & \&: & : & 8 \\
\hline & 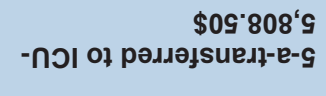 & $\begin{array}{l}\text { o } \\
\infty \\
\infty \\
\infty \\
\infty \\
i\end{array}$ & $\begin{array}{l}8 \\
0\end{array}$ & $\begin{array}{l}0 \\
\infty \\
\infty \\
\infty \\
\infty \\
i \infty\end{array}$ & $\stackrel{8}{8}$ & $\stackrel{8}{8}$ & $\stackrel{8}{\circ}$ & 8 \\
\hline & 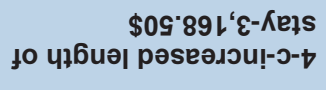 & $\stackrel{8}{\circ}$ & $\stackrel{8}{8}$ & $\stackrel{8}{\circ}$ & $\stackrel{8}{8}$ & $\stackrel{8}{8}$ & $\stackrel{8}{8}$ & 8 \\
\hline & 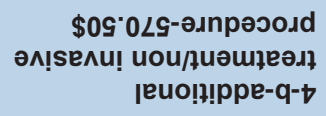 & : & $\begin{array}{l}0 \\
0 \\
0 \\
0 \\
6\end{array}$ & $\stackrel{8}{\circ}$ & $\stackrel{8}{\circ}$ & $\stackrel{8}{\circ}$ & $\begin{array}{l}\text { م⿱ } \\
\text { Dे } \\
\text { in }\end{array}$ & $\stackrel{8}{\circ}$ \\
\hline & 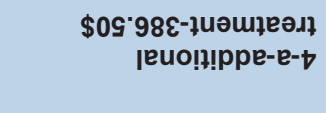 & 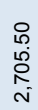 & $\begin{array}{l}8 \\
\varnothing \\
0 \\
0 \\
\infty \\
\infty\end{array}$ & $\begin{array}{l}8 \\
\dot{0} \\
\stackrel{\infty}{m} \\
\stackrel{N}{N}\end{array}$ & 웅 & 8 & 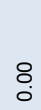 & $\begin{array}{l}0 \\
0 \\
0 \\
0 \\
e \\
e\end{array}$ \\
\hline & 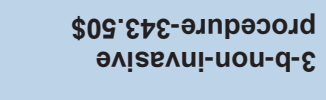 & $\begin{array}{l}8 \\
\stackrel{+}{+} \\
\stackrel{m}{=}\end{array}$ & 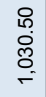 & 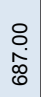 & $\stackrel{8}{0}$ & $\begin{array}{l}0 \\
0 \\
0\end{array}$ & $\stackrel{8}{8}$ & $\begin{array}{l}0 \\
\stackrel{b}{\infty} \\
\stackrel{p}{j}\end{array}$ \\
\hline 8 & 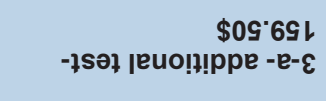 & $\begin{array}{l}\stackrel{\circ}{\circ} \\
\stackrel{0}{\circ}\end{array}$ & $\begin{array}{l}0 \\
\stackrel{0}{0} \\
0 \\
\stackrel{\rho}{\sigma} \\
-\end{array}$ & 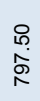 & $\begin{array}{l}8 \\
0 \\
0\end{array}$ & $\begin{array}{l}0 \\
0 \\
0\end{array}$ & $\stackrel{\circ}{\circ}$ & 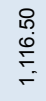 \\
\hline 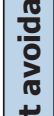 & $\begin{array}{l}\text { \$0S"†9-भ!s!^ } \\
\text { ue!̣!sКyd-z }\end{array}$ & $\begin{array}{l}8 \\
\infty \\
\infty \\
\stackrel{8}{\circ}\end{array}$ & $\begin{array}{l}8 \\
0 \\
0 \\
0 \\
0 \\
0\end{array}$ & $\begin{array}{l}\text { ¿. } \\
\text { ळ. } \\
\text { o. }\end{array}$ & $\begin{array}{l}\stackrel{8}{0} \\
\stackrel{8}{ } \\
\stackrel{-}{-}\end{array}$ & $\begin{array}{l}0 \\
i \\
\dot{5} \\
0\end{array}$ & 8 & $\begin{array}{l}\stackrel{\rho}{1} \\
\stackrel{\infty}{\infty} \\
\infty \\
\stackrel{\sim}{\sim}\end{array}$ \\
\hline$\dot{\varphi}_{y}^{\dot{y}}$ & 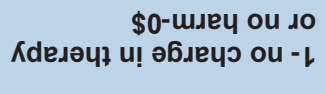 & : & $\begin{array}{l}8 \\
0 \\
0\end{array}$ & \&: & $\stackrel{8}{0}$ & $\begin{array}{l}0 \\
0 \\
0\end{array}$ & $\stackrel{8}{8}$ & \&. \\
\hline$\frac{0}{\frac{0}{0}}$ & $\begin{array}{l}\text { \$0-шәродd рәңе|әд } \\
\text { uо!ןеग!рәш оu-0 }\end{array}$ & $\begin{array}{l}8 \\
0 \\
0\end{array}$ & $\begin{array}{l}8 \\
0\end{array}$ & \&: & $\stackrel{8}{\circ}$ & $\begin{array}{l}0 \\
0 \\
0\end{array}$ & 8 & $\stackrel{8}{0}$ \\
\hline 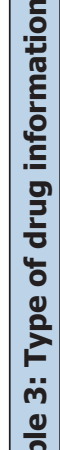 & & 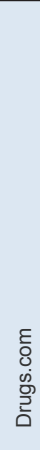 & $\begin{array}{l}0 \\
\frac{0}{0} \\
0 \\
0 \\
0 \\
\Sigma\end{array}$ & 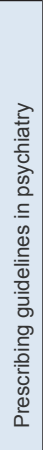 & 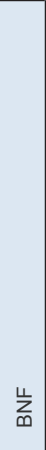 & 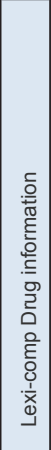 & 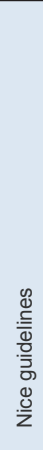 & 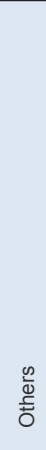 \\
\hline 1 & & - & $\sim$ & $m$ & 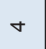 & เ & 0 & 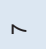 \\
\hline
\end{tabular}

\begin{tabular}{|c|c|c|c|c|c|c|}
\hline & 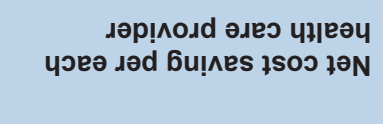 & 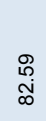 & $\stackrel{8}{\stackrel{8}{1}}$ & 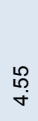 & $\underset{\substack{m \\
+}}{\stackrel{m}{\leftarrow}}$ & $\underset{\infty}{\infty}$ \\
\hline & 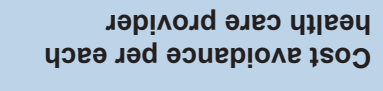 & $\stackrel{\substack{7 \\
\stackrel{\rho}{N}}}{\stackrel{1}{N}}$ & $\begin{array}{l}\bar{\delta} \\
i \\
i\end{array}$ & $\stackrel{\infty}{\stackrel{\infty}{L}}$ & $\begin{array}{l}\bar{\infty} \\
\stackrel{\infty}{f}\end{array}$ & $\underset{\hat{N}}{\hat{N}}$ \\
\hline & 7sos ןеłOL & 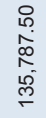 & 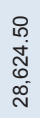 & 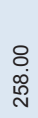 & 号 & $\underset{\frac{8}{5}}{\stackrel{8}{6}}$ \\
\hline & \$000'000‘00เ-Чұеәр-9 & $\begin{array}{l}8 \\
8 \\
8 \\
8 \\
\check{8}\end{array}$ & ¿̊. & $\stackrel{8}{\circ}$ & $\stackrel{8}{\circ}$ & $\stackrel{8}{\circ}$ \\
\hline & 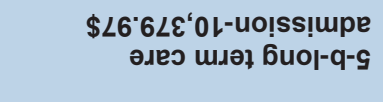 & $\stackrel{8}{8}$ & $\stackrel{8}{8}$ & $\stackrel{8}{\circ}$ & $\stackrel{8}{0}$ & $\stackrel{8}{\circ}$ \\
\hline & 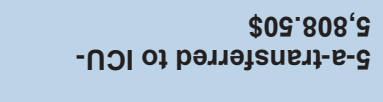 & $\begin{array}{l}0 \\
10 \\
\infty \\
\infty \\
\infty \\
\infty\end{array}$ & $\begin{array}{l}\infty \\
\infty \\
\infty \\
\infty \\
\infty \\
\omega\end{array}$ & $\stackrel{8}{0}$ & \&: & $\stackrel{8}{\circ}$ \\
\hline & 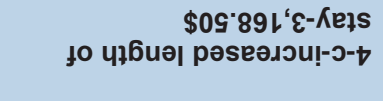 & $\begin{array}{l}8 \\
0\end{array}$ & $\stackrel{8}{0}$ & : & \& & $\stackrel{\circ}{\circ}$ \\
\hline & 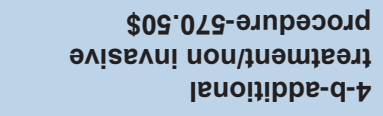 & $\begin{array}{l}8 \\
8 \\
0\end{array}$ & $\underset{0}{8}$ & $\begin{array}{l}8 \\
0 \\
0\end{array}$ & 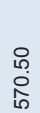 & $\stackrel{8}{\circ}$ \\
\hline & 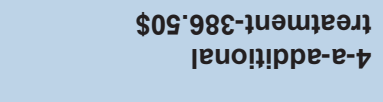 & $\begin{array}{l}8 \\
0 \\
0 \\
\infty \\
\infty \\
\infty\end{array}$ & $\begin{array}{l}8 \\
\stackrel{0}{0} \\
\infty \\
\infty \\
\infty\end{array}$ & 8 & \&: & $\stackrel{8}{8}$ \\
\hline 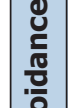 & 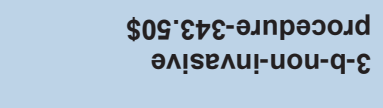 & 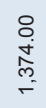 & 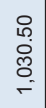 & $\stackrel{\circ}{\circ}$ & : & $\stackrel{8}{\circ}$ \\
\hline 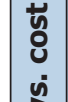 & \$0S'6SL-łSəl ןeuo!!!ppe -e- $\varepsilon$ & 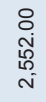 & 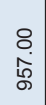 & $\stackrel{8}{\circ}$ & $\begin{array}{l}\text { 足 } \\
\stackrel{\leftrightarrow}{0} \\
\stackrel{0}{\circ}\end{array}$ & 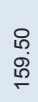 \\
\hline : & \$OS't9-ұ!s!n ue!’!sKud-z & $\begin{array}{l}8 \\
\infty \\
\infty \\
\infty \\
\bar{N}\end{array}$ & 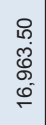 & $\begin{array}{l}8 \\
\infty \\
\infty \\
\stackrel{\infty}{N}\end{array}$ & 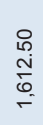 & $\frac{\circ}{\stackrel{\circ}{\circ}}$ \\
\hline ํㅡㄹ & 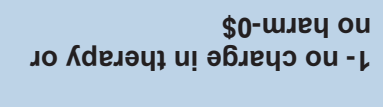 & $\stackrel{8}{0}$ & $\stackrel{8}{0}$ & $\stackrel{8}{\circ}$ & \&: & \&: \\
\hline 일 & 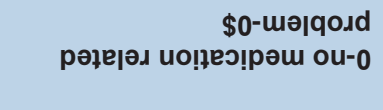 & $\begin{array}{l}8 \\
0\end{array}$ & $\begin{array}{l}8 \\
0\end{array}$ & \&̊. & 8 & \&: \\
\hline $\begin{array}{l}\stackrel{2}{z} \\
\ddot{\dot{y}} \\
0\end{array}$ & & $\begin{array}{l}\frac{c}{.0} \\
\frac{.0}{0} \\
\frac{0}{2} \\
\frac{E}{Q}\end{array}$ & 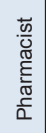 & 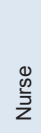 & 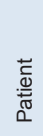 & 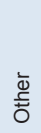 \\
\hline & & - & $\sim$ & $m$ & $\forall$ & is \\
\hline
\end{tabular}




\section{CONCLUSION}

The drug information center is justified services provided to healthcare staff at the Mental hospital in Saudi Arabia. The drug information services demand to expand with higher level services and various type of services. The drug information services need to expand to all mental and psychiatric hospital in Kingdom of Saudi Arabia.

\section{ACKNOWLEDGMENT}

None.

\section{CONFLICT OF INTEREST}

None.

\section{ABBREVIATION USED}

KSA: Kingdom of Saudi Arabia; ASHP: American Society of Health-System Pharmacist; MOH: Ministry of Health; USA: United States of America.

\section{REFERENCES}

1. Alomi YA. National Drug Information Center Program at Ministry of Health in Saudi Arabia. Adv Pharmacoepidemiol Drug Saf. 2016;5(1):1-2.

2. Alomi YA, Alghamdi SJ, Alattyh RA. Strategic Plan of General Administration of Pharmaceutical Care at Ministry of Health in Saudi Arabia 2012 - 2022. J Pharm Pharm Sci. 2015;1(13):1-8.
3. Alomi YA, Mudaiheem HA. National Drug Information Center Services through Ministry of Health Hotline Calling Center (937) in Saudi Arabia. Adv Pharmacoepidemiol Drug Saf. 2016;5(1s).

4. Alomi YA, Almudaiheem HY, Alarnous T, Alshurei S, Alsharafa A, Alzahrani T, et al. Cost-Efficiency of of National Drug Information Center Through Ministry of Healh Hotline Calling Services (937) in Saudi Arabia: Application of a Mercian Model. Value Heal. 2015;18(7):A735.

5. Skoutakis VA, Wojciechowski NJ, Carter CA, Hayes JM, Hudson BL, Martin JA. Drug Information Center network: need, effectiveness, and cost justification. Drug Intell Clin Pharm. 1987;21(1 Pt 1):49-56.

6. Lyrvall H, Nordin C, Jonsson E, Alvan G, Öhman B. Potential savings of consulting a drug information center. Annals of Pharmacotherapy. 1993.27(12):1540.

7. Kinky DE, Erush SC, Laskin MS, Gibson GA. Economic impact of a drug information service. Ann Pharmacother. 1999;33(1):11-6.

8. Marrone CM, Heck AM. Impact of a Drug Information Service: Practitioner Hours Saved. Hosp Pharm. 2000;35(10):1065-70.

9. Ponampalam R, Loh CS. Cost benefits of the Drug and Poison Information Centre in preventing unnecessary hospitalisation: The Singapore experience. Hong Kong J Emerg Med. 2010;17(1):45-53.

10. Brown JN. Cost Savings Associated With a Dedicated Drug Information Service in an Academic Medical Center. Hosp Pharm. 2011;46(9):680-4.

11. Alomi YA. National Pharmacy Practice Programs at Ministry of Health in Saudi Arabia. 2015;1(2):17-8.

Cite this article as: Alomi YA, Alsulami N, Qahtani NA, Qahtani MMA, Almansor FA. Cost Avoidance of Drug Information Services at the Mental Hospital in Saudi Arabia. J Pharm Pract Community Med. 2018;4(2):102-6. 